\title{
THE TRADEMARK USE REQUIREMENT IN DILUTION CASES ${ }^{*}$
}

\author{
Stacey L. Dogan ${ }^{\dagger} \&$ Mark A. Lemley ${ }^{\dagger \dagger}$
}

\begin{abstract}
The trademark use doctrine plays a critical role in ensuring that trademark law serves its proper purpose of encouraging market exchange and lowering consumer search costs. As we have explained in detail elsewhere, ${ }^{1}$ the doctrine ensures that trademarks do not become a weapon used to suppress speech or to interfere with rather than promote the efficient operation of the marketplace.

These goals are even more important in the context of trademark dilution. Unlike a normal cause of action for trademark infringement, trademark dilution gives broader rights to a few famous mark owners to prevent even non-confusing uses in order to protect the uniqueness of their marks against blurring and tarnishment. But because trademark dilution can exist even when goods do not compete, and even absent any likelihood of confusion, it is even more critical that the universe of actions that can give rise to dilution be cabined by a clear and effective trademark use doctrine.

The Lanham Act has had a trademark use limitation on dilution since 1996, but recent amendments have changed the language and scope of that limitation, leading to some confusion about what is and is not protected. ${ }^{2}$ In this article, we parse the language and legislative history of the 2006 Trademark Dilution Revision Act and explain why the trademark use requirement in the new statute not only survives but is more robust than before.

* (C) 2008 Stacey L. Dogan \& Mark A. Lemley. Thanks to Bill Barber, Margreth Barrett, Bob Bone, Graeme Dinwoodie, Eric Goldman, Anne Gundelfinger, Rose Hagan, Laura Heymann, Mark McKenna, and Sandy Rierson for comments on an earlier draft.

$\dagger \quad$ Visiting Professor, Boston University School of Law; Professor of Law; Northeastern University School of Law.

†† William H. Neukom Professor, Stanford Law School; of counsel, Keker \& Van Nest LLP.

1. See Stacey L. Dogan \& Mark A. Lemley, Grounding Trademark Law Through Trademark Use, 92 IowA L. REV. 1669 (2007) [hereinafter Dogan \& Lemley, Grounding Trademark Law]; Stacey L. Dogan \& Mark A. Lemley, Trademarks and Consumer Search Costs on the Internet, 41 Hous. L. REV. 777 (2004).

2. 15 U.S.C.A. § 1125(c)(3)-(4) (West Supp. 2007).
\end{abstract}




\section{BACKGROUND}

\section{A. The Trademark Use Requirement}

The trademark use doctrine requires, as an element of an infringement suit, that a defendant use a trademark "as a mark" to indicate the source or sponsorship of its products or services. ${ }^{3}$ The requirement thus distinguishes between those who brand their products using the plaintiff's mark or some version thereof and others who use the plaintiff's trademark in some non-branding way - for example, by comparing, describing, critiquing, informing, presenting in proximity, learning, commenting, reporting, or simply poking fun. By maintaining the law's focus on misleading branding, the trademark use doctrine keeps trademark law true to its ultimate goal of promoting competitive markets. ${ }^{4}$ While preventing uses that create confusion and misinformation, the law preserves uses that inform rather than deceive, that improve rather than harm the quality of information in markets. ${ }^{5}$

Although it has always informed trademark practice, ${ }^{6}$ the formal trademark use doctrine has evolved in a non-linear and somewhat haphazard way in traditional trademark infringement litigation. Through case-by-case rulemaking, courts have recognized a variety of protected, non-branding uses of marks, and Congress has frequently codified the exemptions. ${ }^{7}$ Descriptive fair use, nominative fair use, the protection for comparative advertising, parody, news reporting, commentary, and criticism have all emerged as categories of nontrademark use exempt from the reach of trademark holders. ${ }^{8}$ More recently, courts have begun to invoke the trademark use doctrine to prevent actions against informational intermediaries, who use marks

3. See Dogan \& Lemley, Grounding Trademark Law, supra note 1, at 1670; Margreth Barrett, Internet Trademark Suits and the Demise of "Trademark Use," 39 U.C. DAVIS L. REV. $371,386 \&$ nn. $41 \& 43$ (2006) (noting cases that discuss the use requirement).

4. See Qualitex Co. v. Jacobson Prods. Co., 514 U.S. 159, 164 (1995) (noting that "trademark law ... seeks to promote competition”).

5. Cf. Eric Goldman, Brand Spillovers (Aug. 24, 2007), http://web.si.umich.edu/tprc/papers/2007/774/brandspilloversv19.pdf (suggesting that trademark law has traditionally tolerated a number of uses that allow others to capture value from brands, particularly where they serve to inform consumers). 82.

6. See generally Dogan \& Lemley, Grounding Trademark Law, supra note 1, at 1675-

7. See id. at 1683-84.

8. Id. 
as indexing tools rather than in branding their products. ${ }^{9}$ All of these "trademark use" exemptions share two features in common: "the defendant has used the mark in [some]... non-source-identifying (and non-sponsorship-identifying) way; and ... the error costs from a pro-plaintiff verdict are high."10 The trademark use doctrine thus serves as a buffer, protecting certain classes of behavior from liability without the uncertainties associated with the traditional "likelihood of confusion" test. ${ }^{11}$

\section{B. Importance in Dilution Cases}

In the dilution context, the need for a trademark use buffer is particularly acute. Unlike traditional trademark infringement - in which confusion over source or sponsorship lies at the heart of the claim $^{12}$ - dilution turns on murkier concepts of "blurring" and "tarnishment" that do not on their face depend on consumer perceptions as to the source of a defendant's product. $^{13}$ Dilution,

9. See, e.g., 1-800 Contacts, Inc. v. WhenU.com, Inc., 414 F.3d 400, 407-11 (2d Cir. 2005) (holding that the sale of trademark-triggered popup ads did not constitute trademark use); Rescuecom Corp. v. Google, Inc., 456 F. Supp. 2d 393, 398-03 (N.D.N.Y. 2006) (finding that sale of keyword-based advertising does not constitute "trademark use").

10. Dogan \& Lemley, Grounding Trademark Law, supra note 1, at 1683.

11. See id. at $1683-85$

12. 15 U.S.C.A §§ 1114, 1125(a) (West Supp. 2007). In theory, a separate trademark use doctrine should be unnecessary in the infringement context, because the likelihood of confusion cannot exist absent some suggestion from the defendant about the source, sponsorship or affiliation of its product - i.e., some form of trademark use. Mark McKenna has argued that the likelihood of confusion inquiry implicitly reflects a trademark use doctrine, but one that turns on consumer perceptions and therefore cannot be decided as a threshold matter. See Mark P. McKenna, Trademark Use and the Problem of Source in Trademark Law, available at http://papers.ssrn.com/sol3/papers.cfm?abstract_id=1088479 (draft, forthcoming); $c f$. Graeme B. Dinwoodie \& Mark D. Janis, Confusion Over Use: Contextualism in Trademark Law, 92 IowA L. REV. 1597, 1646-50 (2007) (critiquing the trademark use requirement as inextricably tied up with questions of confusion). We have more confidence than McKenna does in the courts' ability to carve out some categories of behavior that, as a matter of law, do not constitute trademark use, and we are skeptical of the courts' ability to interpret likelihood of confusion to achieve the same result in a way that avoids enormous cost and uncertainty.

13. Cf. Mattel, Inc. v. MCA Records, Inc., 296 F.3d 894, 905 (9th Cir. 2002) (in contrast to traditional trademark infringement, "dilution ... does not require consumer confusion, ... and dilution injunctions therefore lack the built-in First Amendment compass of trademark injunctions.”); Clarisa Long, Dilution, 106 CoLuM. L. REV. 1029, 1068 (2006) (“By contrast [to dilution law], classic trademark law, with its likelihood of confusion standard, conveys a thinner bundle of use rights to the trademark owner."). We have argued elsewhere that a narrowly defined version of dilution law can lower consumer search costs, and thus that dilution law, properly understood, can fit within the search costs framework. See Stacey L. Dogan \& Mark A. Lemley, The Merchandising Right: Fragile Theory or Fait Accompli?, 54 EMORY L.J. 461, 493-94 (2005) ("Both blurring and tarnishment can make it somewhat more difficult for consumers to associate a famous mark with its owner." Thus "dilution is targeted at reducing 
moreover, does not involve deceptive or confusing speech, or any "fraud on the consuming public."14 As a result, a broad, open-ended dilution statute could target any unauthorized use of a famous trademark, almost without limitation. After all, virtually any reference to a trademark influences the consumer's mental association regarding the brand, in ways that one could characterize as "tarnishing" or "diluting" the trademark holder's carefully crafted commercial identity. ${ }^{15}$

Numerous scholars have explored the costs (and fallacies) associated with such an expansive approach to dilution. Jessica Litman and Rochelle Dreyfuss have critiqued the core notion underlying the dilution theory - the idea of a singular, corporatecrafted brand meaning disengaged from any public role in shaping brand identity. ${ }^{16}$ They and others have pointed out the ways in which broad dilution protection can choke off speech, including speech that serves both competition-oriented and First Amendment values. ${ }^{17} \mathrm{~A}$

consumer search costs”). But there is no question that the relationship is more attenuated with dilution than it is with ordinary trademark infringement. Indeed, many scholars have doubted whether there is any such relationship to consumer interests at all. See, e.g., Robert G. Bone, A Skeptical View of the Trademark Dilution Revision Act, 11 InTEll. Prop. L. Bull. 187, 189193 (2007); David J. Franklyn, Debunking Dilution Doctrine: Toward a Coherent Theory of the Anti-Free-Rider Principle in American Trademark Law, 56 HASTINGS L.J. 117 (2004) (describing the dilution-consumer protection connection as "unnatural," and arguing that dilution should instead be understood as part of a gestalt rule against free riding).

14. Mattel, 296 F.3d at 905 (distinguishing dilution from traditional trademark infringement claims).

15. See generally Laura A. Heymann, Metabranding and Intermediation: A Response to Professor Fleischer, 12 HARV. NEGOT. L. REV. 201, 218-19 (2007) (explaining that in dilution claims, "[t]he brand owner . . . is claiming a right to the exclusive mental association with the brand in the minds of the public.”). Rebecca Tushnet, though generally critical of dilution law, suggests that a dilution law that targets only commercial uses, and ignores the host of other uses that can influence a trademark's meaning, "irrationally targets commercial speech for a harm done by a much larger set of acts." Rebecca Tushnet, Gone in 60 Milliseconds: Trademark Law and Cognitive Science, 82 TEx. L. REV. 507, 566 (2008). See also Rebecca Tushnet, Truth and Advertising: The Lanham Act and Commercial Speech Doctrine, in TRADEMARK LAW AND Theory: A HANDBooK of Contemporary ReSEARCH (Graeme B. Dinwoodie \& Mark D. Janis eds., forthcoming 2008) (manuscript at 26 \& n. 72, available at http://ssrn.com/abstract= 1014418) [hereinafter Tushnet, Truth and Advertising] (contending that a limited dilution doctrine focused solely on commercial uses is arguably unconstitutional, because it is underinclusive and poorly matched to the purported harms caused by dilution).

16. See generally Rochelle Cooper Dreyfuss, Expressive Genericity: Trademarks as Language in the Pepsi Generation, 65 Notre DAME L. ReV. 397 (1990); Jessica Litman, Breakfast with Batman: The Public Interest in the Advertising Age, 108 YALE L.J. 1717, 1733 (1999) (“'Mickey Mouse,' 'Twinkies,' 'Star Wars,' and 'Spam' are trade symbols, but they are also now metaphors with meanings their proprietors would not have chosen. They got that way in spite of any advertising campaigns because the general public invested them with meaning.").

17. See generally Dreyfuss, supra note 16; Litman, supra note 16; Kenneth L. Port, The "Unnatural” Expansion of Trademark Rights: Is a Federal Dilution Statute Necessary?, 85 
broadly defined dilution law could potentially apply to parodies, news reports, consumer commentaries, blog entries, comparative advertising, and a whole host of other means through which speakers inform and enrich our society.

The trademark use doctrine offers a safeguard against dilution law's slippery slope. Dilution law, properly conceived, protects famous marks against uses that interfere with their function as sourceidentifiers. $^{18}$ It should not reach every use that affects a mark's meaning, lest it turn into an über-right that would defeat the very purpose of trademark laws. A robust trademark use doctrine distinguishes between uses that interfere with the source-identifying function of a trademark, on the one hand, and uses that, if anything, affect the mark's meaning as the famous trademark, on the other.

\section{The Use REQUiREMENT BEFORE 2006 - “COMMERCIAL USE IN COMMERCE"}

The Federal Trademark Dilution Act of 1995 (FTDA), Congress's first foray into dilution law, applied only to the "commercial use in commerce of a mark or trade name... [that] causes dilution of the distinctive quality of the mark."19 The statute also specifically exempted "noncommercial use of a mark" from dilution liability. ${ }^{20}$ The legislative history made clear that Congress intended 'commercial use' to cover only those uses that would constitute "commercial speech," as that term is understood in First Amendment jurisprudence. ${ }^{21}$ Commercial speech is speech that "does 'no more than propose a commercial transaction,",22 which, in the trademark context, means a use that has no expressive function except as a brand. ${ }^{23}$

Trademark ReP. 525 (1995); Pratheepan Gulasekaram, Policing the Border Between Trademarks and Free Speech: Protecting Unauthorized Trademark Use in Expressive Works, 80 WASH. L. REV. 887 (2005); Tushnet, Truth and Advertising, supra note 15.

18. See Stacey L. Dogan, An Exclusive Right to Evoke, 44 B.C. L. REv. 291, 320 (2003) (arguing that FTDA should apply only to uses that dilute the singularity of famous marks).

19. Federal Trademark Dilution Act of 1995, Pub. L. No. 104-98, § 3, 109 Stat. 985 (1995) [hereinafter FTDA 1995] (codified at 15 U.S.C. § 1125(c) (2000)).

20. 15 U.S.C. § 1125 (c)(4) (2000).

21. See H.R. REP. NO. 104-374, at 4 (1995) as reprinted in 1995 U.S.C.C.A.N. 1029, 1031. ("Nothing in this section of the bill is intended to alter existing case law on the subject of what constitutes 'commercial' speech.'”).

22. Bolger v. Youngs Drug Prods. Corp., 463 U.S. 60, 66 (1983) (quoting Va. Pharmacy Bd. v. Va. Citizens Consumer Council, Inc., 425 U.S. 748, 762 n.24 (1976)).

23. See Mattel, Inc. v. MCA Records, Inc., 296 F.3d 894, 907 (9th Cir. 2002) (holding that, even though recording label "used Barbie's name to sell copies of [its] song," the use was 
Not all courts have viewed the "commercial use in commerce" 24 language as incorporating a trademark use requirement. Some early courts, apparently moved by the equities of the case before them, found the "commercial use in commerce" requirement satisfied by flimsy connections between the defendant's behavior and the commercial world. In Planned Parenthood Federation of America, Inc. $v$. Bucci, ${ }^{25}$ for example, the court found a commercial use by a website operator because (1) the website was plugging a third party's book (but obtaining no financial gain from book sales or otherwise), (2) the defendant was politically active and solicited donations (albeit none from his website) for his anti-abortion activities, and (3) the use had a negative effect on the plaintiff's commercial activities. ${ }^{26}$ Margreth Barrett has complained that courts repeatedly misunderstood the commercial use requirement in ways that have "significantly impaired First Amendment interests.,"27

Over time, however, judges applying the FTDA showed an increasing recognition of the equivalence between "commercial use in commerce" and "commercial speech." In recent years, virtually all courts have shown a reluctance to enjoin behavior that does not use the trademark as a brand in some way. ${ }^{28}$ The Restatement (Third) of Unfair Competition makes it clear that dilution law imposes such a

noncommercial because "the song also lampoons the Barbie image and comments humorously on the cultural values Aqua claims she represents."). The legislative history provides additional indirect support for the position that the FTDA was concerned only with branding-type uses of famous marks. In testimony and Congressional reports, legislators repeatedly offered "DUPONT shoes, BUICK aspirin, and KODAK pianos" as examples of the harms the statute was intended to address. H.R. REP. No. 104-374, at 3 (1995).

24. 15 U.S.C. § 1125(c)(1) (2000).

25. Planned Parenthood Fed’n of Am., Inc. v. Bucci, No. 97-Civ-0629, 1997 WL 133313 (S.D.N.Y. Mar. 24, 1997).

26. See id. at *5-6.

27. Margreth Barrett, Domain Names, Trademarks and the First Amendment: Searching for Meaningful Boundaries, 39 ConN. L. REV. 973, 973 (2007).

28. See Lamparello v. Falwell, 420 F.3d 309, 313 (4th Cir. 2005) (explaining, in dictum, that FTDA applies only to "commercial speech" in the First Amendment sense); see Mattel, Inc. v. MCA Records, Inc., 296 F.3d 894, 907 (9th Cir. 2002) (finding commercial speech requirement in trademark's “noncommercial use” exemption); $c f$. Universal Commc’n Sys., Inc. v. Lycos, Inc., 478 F.3d 413, 424 (1st Cir. 2007) (rejecting a state dilution claim because "Lycos might profit by encouraging others to talk about UCS under the UCSY name, but neither that speech nor Lycos's providing a forum for that speech is the type of use that is subject to trademark liability.”); Bosley Med. Inst., Inc. v. Kremer, 403 F.3d 672, 676 (9th Cir. 2005) ("While the meaning of the term 'commercial use in commerce' is not entirely clear, we have interpreted the language to be roughly analogous to the 'in connection with' sale of goods and services requirement of the infringement statute [15 U.S.C. § 1114(1)(a)].”). 
requirement. $^{29}$ Given the legislative history, and the otherwiseinexplicable choice of the inartful phrase "commercial use in commerce," we think this was the right understanding of that language.

\section{THE USE REQUIREMENT UNDER THE TDRA}

\section{A. What the TDRA Does}

The Trademark Dilution Revision Act of 2006 was enacted in response to the Supreme Court decision in Moseley v. V Secret Catalogue, ${ }^{30}$ which held that the original 1996 statute applied only in cases where the plaintiff could prove "actual dilution," rather than mere likelihood of dilution. ${ }^{31}$ That decision also questioned whether tarnishment could ever constitute dilution. ${ }^{32}$ Together, these holdings made it extraordinarily difficult for plaintiffs to prove a dilution claim. $^{33}$ They also created an odd disconnect between the liability structure of the dilution law and its remedies. The ordinary remedy in dilution cases is an injunction against future diluting efforts. ${ }^{34}$ But it makes little sense to require plaintiffs to wait until their mark is actually diluted, and then offer them only an injunction against future dilution - rather like closing the barn door after the horse is gone.

Congress acted to undo the effect of Moseley, both by restoring the likelihood of dilution standard that was the majority rule before Moseley $^{35}$ and by making it clear that the cause of action extended to tarnishment as well. ${ }^{36}$ It also reversed the holding of the Second Circuit that had prevented descriptive marks such as McDONALDS from ever qualifying for dilution $\equiv$ ection, ${ }^{37}$ changing the statute to

29. RESTATEMENT (THIRD) OF UNFAIR COMPETITION § 25(1) (1995) (“An actor is subject to liability under an antidilution statute if the actor uses such a designation in a manner that is likely to associate the other's mark with the goods, services, or business of the actor.") (emphasis added).

30. Moseley v. V Secret Catalogue, Inc., 537 U.S. 418 (2003).

31. Id. at 432-33.

32. See id. at 432 .

33. Indeed, Clarisa Long's study found that only $9.52 \%$ of dilution claims were succeeding by 2005. Long, supra note 13, at 1045.

34. 15 U.S.C.A § 1125(c)(5) (West Supp. 2007).

35. Id. § 1125(c)(1).

36. Id.

37. See TCPIP Holding Co v. Haar Commc'ns Inc., 244 F.3d 88, 90 (2d Cir. 2001) (holding that a descriptive mark lacking inherent distinctiveness did not qualify for FTDA protection). 
make it clear that famous marks could include ones that had acquired distinctiveness. $^{38}$

Not all the changes in the law expanded protections for trademark owners, however. Responding to a number of courts that had expanded dilution protection beyond nationally famous marks to include a number of rather obscure ones, ${ }^{39}$ Congress changed the law to make it clear that a famous mark must be "widely recognized by the general consuming public of the United States." 40 In so doing, it eliminated the concept of "niche fame" in particular regions or among specialized groups, and made it clear to courts that dilution was a law to be applied sparingly. Further, Congress substantially expanded the list of exclusions from the reach of the dilution statute, expressly including parody, criticism, commentary, nominative and descriptive fair use in addition to previous exceptions from the reach of the act. ${ }^{41}$ Finally, it may have substantially expanded the preemption of state and perhaps even federal laws by expanding a defense for the owners

38. 15 U.S.C.A. § 1125(c)(1) (West Supp. 2007).

39. See, e.g., Archdiocese of St. Louis v. Internet Entm't Group, Inc., 34 F. Supp. 2d 1145 (E.D. Mo. 1999) (holding "Papal Visit 1999” famous for the Pope's 1999 visit to St. Louis); Nailtiques Cosmetic Corp. v. Salon Scis. Corp., 41 U.S.P.Q.2d 1995, (S.D.Fla. Jan. 10, 1997) (holding "Nailtiques" famous for fingernail care products, and diluted by "ProTechniques”); TeleTech Customer Care Mgmt., Inc. v. Tele-Tech Co., 977 F. Supp. 1407, 1413 (C.D. Cal. 1997) (finding "TeleTech" "probably famous" for customer care information services, and that "teletech.com" was infringing but "tele-tech.com" was not); Gazette Newspapers, Inc. v. The New Paper, Inc., 934 F. Supp. 688, 694, 696 (D. Md. 1996) (holding "Gazette” famous for local Maryland paper); Intermatic Inc. v. Toeppen, 947 F. Supp. 1227, 1236 (N.D. Ill. 1996) (holding "Intermatic” famous for electrical products); Wawa Inc. v. Haaf, 40 U.S.P.Q.2d 1629, 1631, (E.D. Pa. 1996) (holding "Wawa” famous for convenience stores in Pennsylvania and surrounding states); Wedgwood Homes, Inc. v. Lund, 659 P.2d 377, 380-81 (Or. 1983) (holding "Wedgwood" famous for house builders in eastern Washington County, Oregon); Mark A. Lemley, The Modern Lanham Act and the Death of Common Sense, 108 YALE L.J. 1687, 1698 (1999):

[C]ourts applying the state and federal dilution statutes have been quite willing to conclude that a local favorite, or a rather obscure company, is 'famous' within the meaning of the Act. Thus, marks such as Intermatic, Gazette, Dennison, Nailtiques, TeleTech, Wedgewood (for new homes, not china), Papal Visit 1999 and Wawa have been declared famous.

Other courts had been willing to apply dilution without even finding fame. One commentator reports that of the 16 cases she examined, "half did not make an explicit finding that the mark in question was famous, or made such a finding only by confusing fame with distinctiveness." Lori Krafte-Jacobs, Comment, Judicial Interpretation of the Federal Trademark Dilution Act of 1995, 66 U. CIN. L. REV. 659, 690 (1998).

40. 15 U.S.C.A. § 1125(c)(2)(A) (West Supp. 2007).

41. Id. § 1125(c)(3). 
of registered marks, though it is not clear Congress intended this result. $^{42}$

\section{B. The Requirement that the Defendant Use a "Mark or Trade Name"}

The final change - and the one with which we are concerned involves the TDRA's clarification that the defendant must make use of its own "mark or trade name" to violate the statute. ${ }^{43}$ In particular, the TDRA, unlike the FTDA, distinguishes between the "mark or trade name" used by the defendant and the "famous mark." 44 To

42. Id. § 1125(c)(6). This section now provides that a defendant's federal registration is a complete bar not only to a state dilution claim but also to any claim "of actual or likely damage or harm to the distinctiveness or reputation of a mark", id., apparently whether brought on the basis of state or federal law. While the plain language of this provision would appear to bar all federal dilution claims against owners of registered marks, the language almost certainly resulted from a drafting error. The original House bill provided that federal registration:

[S]hall be a complete bar to an action against that person, with respect to that mark, [1] that is brought by another person under the common law or a statute of a State and [2] that seeks to prevent dilution by blurring or dilution by tarnishment, or that asserts any claim of actual or likely damage or harm to the distinctiveness or reputation of a mark, label, or form of advertisement.

H.R. 683, 109th Cong. (2005). While even this language could be clearer, it strongly suggests that registration would have provided a complete defense only to state law claims for dilution by blurring, dilution by tarnishment, or other causes of action based on harm to a mark's distinctiveness or reputation. The apparent preemption of all claims (federal and state) appeared later, and presumably inadvertently, as a result of the reorganization of the section.

43. 15 U.S.C.A. §§ 1125(c)(1), (c)(2)(B)-(C), (c)(5)(A) (West Supp. 2007).

44. The FTDA also referred to "use ... of a mark or trade name," but unlike the TDRA, the grammatical context of that sentence suggested that the "mark or trade name" referred to in the old statute was the plaintiff's famous mark. 15 U.S.C. § 1125(c)(1) (2000) (limiting dilution to a "person's commercial use in commerce of a mark or trade name, if such use . . . causes dilution of the distinctive quality of the mark"). At a minimum, this language did not clearly distinguish between the "mark or trade name" used by the defendant, on the one hand, and the famous mark, on the other. That language did not, standing alone, create a trademark use requirement in the FTDA; that requirement was found in the awkward and oft-misunderstood phrase "commercial use in commerce." The TDRA eliminates this ambiguity by clearly distinguishing between the defendant's mark or trade name, on the one hand, and the diluting effect on the famous mark, on the other. And it repeatedly invokes that distinction. The structure of the TDRA thus emphasizes and reinforces the significance of the trademark use requirement in a way that the FTDA did not. It is simply not accurate to contend, as Bill Barber does, that the FTDA and the TDRA are identical except for the TDRA's requirement of "commercial” use. See William G. Barber, Dumping the "Designation of Source" Requirement from the TDRA: A Response to the Alleged "Trademark Use Requirement" in Dilution Cases, 24 SANTA Clara COMPUTER \& High TECH. L.J _ (2008). The entire structure of the sentence was changed in a way that makes it clear that both the defendant and the plaintiff must have separate marks in order for the statute to apply.

Barber's proffered explanation - that the reference to the defendant's use of "a mark or trade name" is meant to refer to use of the plaintiff's mark - has another problem as well. It would limit the scope of dilution to defendant's marks that are identical to the plaintiff's, since 
understand the effect of this language, it is necessary to look at it in the context in which it appears in the statute:

(c) Dilution by Blurring; Dilution by Tarnishment

(1) Injunctive Relief

Subject to the principles of equity, the owner of a famous mark that is distinctive... shall be entitled to an injunction against another person who ... commences use of a mark or trade name in commerce that is likely to cause dilution by blurring or dilution by tarnishment of the famous mark ....

(2) Definitions

(B) For purposes of paragraph (1), "dilution by blurring” is association arising from the similarity between a mark or trade name and a famous mark that impairs the distinctiveness of the famous mark. In determining whether a mark or trade name is likely to cause dilution by blurring, the court may consider all relevant factors, including the following:

(i) The degree of similarity between the mark or trade name and the famous mark.

(v) Whether the user of the mark or trade name intended to create an association with the famous mark.

(vi) Any actual association between the mark or trade name and the famous mark. ...

(C) For purposes of paragraph (1), “dilution by tarnishment" is association arising from the similarity between a mark or trade name and a famous mark that harms the reputation of the famous mark.

otherwise the defendant would not be using the plaintiff's mark or trade name. Under Barber's interpretation, therefore, Congress inadvertently excluded from the scope of dilution any uses by defendants of terms that were not identical to the plaintiff's mark, including Moseley's use of Victor's Secret. It need hardly be said that an interpretation of the statute that fails to overrule the very case Congress intended to overrule is likely not the correct one. 


\section{(5) Additional Remedies}

The owner of the famous mark shall also be entitled to the remedies set forth [elsewhere] ... if-

(A) the mark or trade name that is likely to cause dilution by blurring or dilution by tarnishment was first used in commerce by the person against whom the injunction is sought after the date of enactment of the Trademark Dilution Revision Act of 2006. ... ${ }^{45}$

The grammatical structure of this statute is clear. The defendant's use - the thing that may cause dilution by blurring or dilution by tarnishment - is not just any use or reference to the plaintiff's famous mark, but a specific, limited class of uses - use of a term by the defendant as "a mark or trade name." 46 It is only such a use that can cause the injury described in section (2), and can give rise to the remedies in sections (1) and (5). ${ }^{47}$

It is equally clear from this language that the reference to the defendant's "mark or trade name" is not just a placeholder for use of the plaintiff's mark. There are two marks being discussed in the statute - "the famous mark" owned by the plaintiff and the "mark or trade name" used in commerce by the defendant. ${ }^{48}$ This is evident from the repeated references to the two in the same sentence, which would make no sense if the two marks were the same, and from the repeated references to similarities, differences and associations between the famous mark and the defendant's "mark or trade name."49

"Trademark" and "trade name," in turn, have definitions in the statute. A "trade name" is "any name used by a person to identify his or her business or vocation." 50 A trademark is "any word, name, symbol, or device ... used by a person ... to identify and distinguish

45. 15 U.S.C.A. §§ 1125(c)(1), (c)(2)(B-C), (c)(5)(A) (West Supp. 2007) (italics and boldface added).

46. Id.

47. $\S 1125(c)(1)-(2),(5)$.

48. § 1125(c)(2).

49. For this reason, Dinwoodie \& Janis's objection that the language requires use "of" a mark or trade name rather than use "as" a mark or trade name is of no consequence. Graeme B. Dinwoodie \& Mark D. Janis, Dilution's (Still) Uncertain Future, 105 Mich. L. ReV. FIRST IMPRESSIONS 98, $101 \quad$ (2006), http://www.michiganlawreview.org/firstimpressions/vol105/dinwoodie.pdf. The "mark or trade name" referred to cannot be the plaintiff's famous mark, and must be the defendant's mark.

50. 15 U.S.C.A. $§ 1127$ (West Supp. 2007). 
his or her goods ... from those manufactured or sold by others and to indicate the source of the goods." 51

It follows that the only actionable "uses" by a defendant of the plaintiff's famous mark are those in which a defendant uses a trademark or trade name to identify and distinguish its own goods and services. Other uses alleged to dilute cannot satisfy the terms of the statute.

The legislative history of the TDRA is generally unhelpful, but to the extent anything can be gleaned from it, it supports the commonsense reading of the statute set forth above. ${ }^{52}$ The original version of the statute supported by the International Trademark Association (INTA) required that the defendant make use of a "designation of source." 53 The Committee Chair accordingly referred to dilution as "arising from the similarity between a source designation and a famous mark." "54 Bill Barber objected on behalf of the American Intellectual Property Law Association (AIPLA) that the term "designation of source" did not have a settled meaning in trademark law, claiming (wrongly) that it was a "completely new requirement in dilution jurisprudence" rather than a replacement for the "commercial use in commerce" language, ${ }^{55}$ and proposed a different approach

51. Id.

52. Bill Barber's description of the TDRA's "legislative history” illustrates not only the danger of private lawmaking, but the unreliability of unwritten witness accounts of such lawmaking. Barber, supra note 44, at _. He claims that the interested private parties had reached a "consensus" that the TDRA, as enacted, reflected no trademark use requirement. Id. at Xxx But he fails to point to any concrete support for such a private consensus, let alone any consensus among the legislators who passed this federal law. To the contrary, at least two of the parties that testified before Congress about trademark use - Mark Lemley and Anne Gundelfinger, the then-president of the International Trademark Organization (INTA) - have an understanding that comports with the plain reading of the statute and the one we articulate here: that the TDRA requires trademark use as a basis for liability.

53. Trademark Dilution Revision Act of 2005: Hearing on H.R. 683 Before the Subcomm. on Courts, the Internet, and Intellectual Property of the H. Comm. on the Judiciary, 109th Cong. 15-17 (2005) (statement of Anne Gundelfinger, President, INTA) [hereinafter Hearing on H.R. $683]$.

54. Id. at 2 .

55. Id. at 21-22 (statement of William G. Barber, Partner, Fulbright and Jaworski, LLP, on behalf of AIPLA). For an explanation of why Barber was mistaken to suggest that dilution had never had a trademark use requirement, see id. at 18-19, 21 (testimony of Mark A. Lemley, Professor of Law, Stanford University). Barber has also suggested that trademark infringement generally also lacks a use requirement. William G. Barber, The Trademark Dilution Revision Act of 2005: Breathing Life Back into the Federal Dilution Statute, 16 FordHAM INTELL. Prop., MEDIA \& ENT. L.J. 1113, 1132 (2006) [hereinafter Breathing Life] ("Just as a non-trademark use can create a likelihood of confusion (and thus constitute trademark infringement), it can likewise create a likelihood of dilution."). We have explained in detail why he is wrong on this point as 
altogether, one that would have created liability for dilution regardless of the nature of the use by the defendant. ${ }^{56}$

Rather than accept Barber's suggestion, the committee simply dropped the term "designation of source" and left in place "mark or trade name,” following INTA's explanation that

"[d]esignation of source" is an accepted term of art in trademark law that is easily understandable.... [It] simply requires that, in order for a dilution case to proceed, the plaintiff must show that the defendant is using the challenged mark as a mark or name for his own company, goods, or services. ${ }^{57}$

Thus, it seems evident that the committee resolved this dispute in favor of maintaining a trademark use requirement in the dilution statute, merely eliminating the proposed "designation of source" language in favor of language that meant the same thing and was already defined in the statute.

This reading is also consistent with House Chairman Lamar Smith's statement that the bill did not break new ground, and "represents a clarification of what Congress meant when it passed the dilution statute almost a decade ago." 58 Given the existence of the "commercial use in commerce" requirement in the old statute, setting forth trademark use as a prerequisite to liability, it seems quite clear that the House did not intend to drop any trademark use requirement and therefore to expand dilution law dramatically to permit suits against dictionaries, parodists, and a host of others who are not using the plaintiff's mark to sell anything. ${ }^{59}$

well: the law does in fact impose such a requirement. See Dogan \& Lemley, Grounding Trademark Law, supra note 1, at 1675-82.

56. Specifically, Barber suggested defining dilution by blurring as "impairment of association between the famous mark and a single source" Hearing on H.R. 683, supra note 53, at 29. This language contrasts sharply with the definition ultimately adopted, which concerns itself only with impairments to a mark's distinctiveness that result from "association arising from the similarity between a mark or trade name and a famous mark" 15 U.S.C.A § 1125(c)(2)(B) (West Supp. 2007).

57. Hearing on H.R. 683, supra note 53. at 15 (statement of Anne Gundelfinger, President, INTA) (emphasis added). Cf. 4 J. THOMAS MCCARTHY, MCCARTHY ON TRADEMARKS AND UNFAIR COMPETITION \$24:101 (4th ed. 2007) (in the absence of direct legislative history, relying on Gundelfinger's testimony to determine likely legislative intent).

58. Hearing on H.R. 683, supra note 53, at 2 (statement of Hon. Lamar S. Smith, Chairman, Subcomm. On Courts, the Internet, and Intellectual Property).

59. Cf. id. at 26 (Barber's suggestion that dilution law be expanded to permit lawsuits against those who use a term in its generic sense against the wishes of the trademark owner, and that the trademark use requirement needed to be dropped from the statute to achieve that result.). While Barber's testimony and article read as though trademark owners had an established right to sue those who use a term in its generic sense, no court has established such a right, and the 
Finally, we think this understanding is consistent with the language of subsection (3), which provides a host of "exclusions" from the reach of the dilution statute. Those exclusions include two more provisions that might be thought to establish a trademark use requirement: section (c)(3)(A), which protects "any fair use ... of a famous mark by another person other than as a designation of source for the person's own goods or services," and section (c)(3)(C), which protects "[a]ny noncommercial use of a mark." 60 We acknowledge that the presence of these three different takes on the same basic issue is confusing, and might even lead some to suggest that the references to "mark or trade name" in the other subsections should not be read to mean what they say. But we think that is the wrong approach. Like the 1996 Act before it, which spoke of "commercial use in commerce" and separately exempted "noncommercial use of a mark," ${ }^{, 61}$ Congress in the 2006 revisions appeared to take a "belt and suspenders" approach, throwing in a variety of language in an effort to define a universe of conduct the new law did not reach. For example, it included separate exclusions for "commenting upon the famous mark owner" and for "news commentary,", reason to believe that one of these provisions limits or renders inoperative the other. Rather, Congress was trying to make sure that this conduct - and uses other than those of a mark or trade name was not covered by the statute. That overlap may mean that one or more of these provisions end up being superfluous, ${ }^{63}$ but that is better than the alternative. It would be perverse to conclude that an excess of Congressional enthusiasm for the trademark use requirement should be interpreted to have the opposite effect of undermining it. ${ }^{64}$

Seventh Circuit, the Restatement, and the leading treatise all argue against it. See Ty Inc. v. Perryman, 306 F.3d 509, 513-14 (7th Cir. 2002); REstatement (THIRD) OF UNFAIR COMPETITION § $25 \mathrm{cmt}$. i (1995); MCCARTHY, supra note 57, at § 24:75. And even Barber no longer appears to take that position, since he refers to his own prior argument as a "straw man" in his article in this symposium. See Barber, supra note 44, at -

60. 15 U.S.C.A § 1125(c)(3)(A),(C) (West Supp. 2007).

61. See Mattel, Inc. v. MCA Records, Inc., 296 F.3d 894, 904-05 (9th Cir. 2002) (noting this overlap in the 1996 legislation, and reading the "non-commercial use" provision to immunize any protected First Amendment expression, even if done for profit.)

62. 15 U.S.C.A. § 1125(c)(3) (West Supp. 2007).

63. See Dinwoodie \& Janis, supra note 49 , at 102.

64. It is also worth noting that 15 U.S.C.A. § 1125(c)(3) is styled as "exclusions" from the scope of the act, not as defenses to an otherwise viable cause of action, further undermining the idea that the presence of a "designation of source" or "noncommercial use" limitation in that section implies that the general bill reaches further than that. Indeed, the fact that none of these exclusions applies if a defendant is using a mark as a source-identifier reinforces the notion that a defendant's source-identifying use is what triggers the statute. 


\section{Changes Under the New Regime}

What is the effect of the new language on trademark use?

It should be clear that the TDRA incorporates a trademark use requirement. ${ }^{65}$ Only defendants who use a term as a mark or trade name will face potential liability for dilution. Hopefully this language - defined in the statute - will be easier for courts to understand than the unfortunate "commercial use in commerce" language in the 1996 Act. ${ }^{66}$ Regardless, it should be clear that the basic intent of the new language is the same as the old - to cabin the reach of dilution law to cases in which the defendant is branding goods or services with the diluting mark, and prevent it from being used as a weapon against parodists, newspapers, dictionaries, artists, and the wide variety of people who use trademarks as part of their mode of expression. ${ }^{67}$

65. See MCCARTHY, supra note 57, § 24:99, 24:101 (an element of dilution under the TDRA is that "the defendant is making use of the challenged designation as a mark or trade name ... . This means that non-mark uses, as in the content of expressive works, are not reached by the Act.”); accord Dinwoodie \& Janis, Confusion Over Use, supra note 12, at 1631 n.148 (" $[\mathrm{T}]$ he statutory amendments that were enacted will most likely be read to include such a [trademark use] requirement”); cf. Dinwoodie \& Janis, Dilution's (Still) Uncertain Future, supra note 49, at 101 ("If Congress was trying to enact a trademark use requirement, it did so inartfully.”).

66. Cf. Dinwoodie \& Janis, Dilution's (Still) Uncertain Future, supra note 49, at 101 (suggesting that courts were coming to a consensus over the meaning of this language before the 2006 revisions, and the 2006 revisions reinjected uncertainty). To the contrary, we think the 2006 language clarifies the trademark use requirement and eliminates the risk of a court finding dilution in any remotely "commercial use," such as parody or criticism sites that sell advertising space or offer unrelated products for sale. See supra notes 25-27 and accompanying text.

67. See Dreyfuss, supra note 16. Indeed, one could argue that the language chosen to express this trademark use requirement - the requirement that a defendant make "use of a mark or trade name" - will end up being narrower than its predecessor or the "designation of source" alternative in the original bill. After all, some courts might interpret "commercial use in commerce" to encompass things other than marks and trade names - use in advertising or promotion, for instance, provided it "does no more than propose a commercial transaction." See H.R. REP. NO. 104-374, at 4 (1995) as reprinted in 1995 U.S.C.C.A.N. 1029, 1031. (adopting the First Amendment definition of commercial speech - "speech which does no more than propose a commercial transaction" - as the limit of the reach of the original dilution statute). Cf. Deere \& Co. v. MTD Prods., Inc., 41 F.3d 39, 43 (2d Cir. 1994) (holding that the New York state dilution statute applies "when the plaintiff's trademark is linked to products of shoddy quality, or is portrayed in an unwholesome or unsavory context likely to evoke unflattering thoughts about the owner's product") (emphasis added). Similarly, "designation of source" might have extended beyond pure uses of a mark to encompass certain advertising uses that suggested affiliation or sponsorship, although such uses are arguably less likely to occur in the dilution than the "passing off" context. McKenna, supra note 12, at 32-33 (arguing that trademark use cannot be determined without reference to consumer confusion). Although we think each of the articulations of trademark use means the same thing, the TDRA clarifies and cleans up the trademark use requirement and ensures that dilution can apply only to defendants that use marks as brands. 
The only appellate decision thus far addressing the TDRA appears to recognize the statute's requirement of trademark use. In Louis Vuitton v. Haute Diggity Dog, ${ }^{68}$ the Fourth Circuit considered a dilution claim by Louis Vuitton against the seller of a "Chewy Vuitton" brand squeak toy whose brand was an obvious parody of the famous fashion house. The court recognized that the parody did not fall within the statutory "fair use" exception, because the defendant had used the parody as a designation of source. ${ }^{69}$ At the same time, the court agreed with the district court that the parody did not "blur" the distinctiveness of the Louis Vuitton mark. ${ }^{70}$ For several reasons because the defendant mimicked the mark rather than replicating $\mathrm{it}^{71}$ because the parody successfully simultaneously evoked and poked fun, ${ }^{72}$ and because the mark was so famous that the public would get the joke ${ }^{73}$ - the court held that Louis Vuitton had not met its burden of proving likelihood of dilution. ${ }^{74}$

While Louis Vuitton did not directly address the TDRA's trademark use requirement because the defendant had clearly engaged in a trademark use, the court's opinion reinforces the notion that the TDRA limits itself to defendants who use marks as brands. Throughout the opinion, the court described dilution as the statute does: a defendant's use of a mark in a way that dilutes a famous mark's distinctiveness. $^{75}$

68. Louis Vuitton Malletier v. Haute Diggity Dog, LLC, 507 F.3d 252 (4th Cir. 2007).

69. Id. at 266 ("Under the statute's plain language, parodying a famous mark is protected by the fair use defense only if the parody is not 'a designation of source for the person's own goods and services."”).

70. Id. at 267 ("Indeed, by making the famous mark an object of the parody, a successful parody might actually enhance the mark's distinctiveness by making it an icon. The brunt of the joke becomes yet more famous.”).

71. Id. at 268 ("Haute Diggity Dog mimicked the famous marks; it did not come so close to them as to destroy the success of its parody and, more importantly, to diminish the LVM marks' capacity to identify a single source.”).

72. Id. at 267 ("Even as Haute Diggity Dog's parody mimics the famous mark, it communicates simultaneously that it is not the famous mark, but only satirizing it.").

73. See id. (noting that "because the famous mark is particularly strong and distinctive, it becomes more likely that a parody will not impair the distinctiveness of the mark.").

74. Id. at 268-70.

75. Id. at 266 ("The TDRA prohibits a person from using a junior mark that is likely to dilute (by blurring) the famous mark, and blurring is defined to be an impairment of the famous mark's distinctiveness.") (emphasis added); id. (“To determine whether a junior mark is likely to dilute a famous mark through blurring, the TDRA directs the court to consider all factors relevant to the issue"); id. at 268 ("To establish its claim for dilution by tarnishment, LVM must show ... that [defendant's] use of the "Chewy Vuitton" mark on dog toys harms the reputation" of the famous mark). 


\section{CONCLUSION}

The TDRA clearly includes a trademark use requirement. If anything, the TDRA has made it harder to prove dilution claims, not only reaffirming but actually tightening up on the universe of conduct that can be considered dilution. Bill Barber has it exactly backwards, then, to call this change "a huge win to trademark owners."76 Far from abolishing the existing trademark use requirement, as Barber appears to have hoped, the inclusion of more restrictive language in the 2006 revisions strengthens that requirement. This tougher limit makes sense for society, even if trademark owners will not necessarily be happy: dilution is a more powerful right than trademark infringement, and should be applied carefully and with an eye to the costs of overreaching protection. In their joint written submission to Congress, INTA and AIPLA said that the goal of the revised bill incorporating the "mark or trade name" requirement was to "narrow and better focus dilution protection, providing famous mark owners a provable cause of action, while at the same time protecting free speech." 77 The TDRA can plausibly be said to achieve those worthy aims only if it is understood as it is written, to require trademark use by the defendant.

76. Barber, Breathing Life, supra note 55, at 1132.

77. Hearing on H.R. 683, supra note 53, at 53. 